\title{
Dexamethasone/Selinexor Regimen
}

National Cancer Institute

\section{Source}

National Cancer Institute. Dexamethasone/Selinexor Regimen. NCI Thesaurus. Code C162355.

A regimen consisting of dexamethasone and selinexor that may be used for the treatment of relapsed or refractory multiple myeloma. 